\title{
Analysis of the BACE1 and Clusterin Genes Expression Levels in Alzheimer's Disease
}

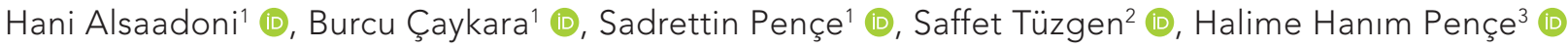 \\ 1Department of Molecular Medicine, İstanbul University Aziz Sancar Institute of Experimental Medicine (ASDETAE), İstanbul, Turkey \\ 2Department of Neurosurgery, İstanbul University-Cerrahpaşa, Cerrahpaşa School of Medicine, İstanbul, Turkey \\ ${ }^{3}$ Department of Medical Biochemistry, University of Health Sciences, School of Medicine, İstanbul, Turkey
}

Cite this article as: Alsaadoni H, Çaykara B, Pençe S, Tüzgen S, Pençe HH. Analysis of the BACE1 and Clusterin Genes Expression Levels in Alzheimer's Disease. JAREM 2019; 9(1): 45-9.

\begin{abstract}
Objective: This study aimed to explore the mRNA expressions of the $\beta$-site amyloid precursor protein-cleaving enzyme 1 (BACE1) and clusterin (CLU) genes in blood samples of patients with Alzheimer's disease (AD) and healthy subjects.

Methods: The expression levels of CLU and BACE1 in blood samples of subjects were examined using the real-time polymerase chain reaction (RT-PCR). The expression levels of patient and control groups were calculated using the $2-\triangle \triangle C t$ method. The Statistical Package for Social Sciences (SPSS) version 22 (IBM Corp., Armonk, NY, USA) was used for statistical analysis, and a p of $<0.05$ was accepted as statistically significant.

Results: The BACE1 and CLU genes were found 14-fold and 13-fold more expressed in the blood of the AD group than on the control group, respectively.

Conclusion: Our study showed that the blood mRNA levels of the BACE1 and CLU genes were associated with AD.

Keywords: Alzheimer's disease, BACE1, clusterin, gene expression
\end{abstract}

\section{INTRODUCTION}

Alzheimer's disease (AD) currently affects 44.4 million people worldwide (1), including 5.3 million Americans, and this number is estimated to triple by the year 2050 (2). As the prevalence of AD increases, the $A D$-associated economic burden will also increase (2). Early-onset $A D(E O A D)$ occurs before the age of 65, and lateonset Alzheimer disease (LOAD) appears after the age of 65 (3). Alzheimer's prevalence is found to be $6.4 \%$ in individuals aged 65 years and older in Turkey (4).

The accumulation of amyloid beta peptide $(A \beta)$ and fibrillar plaques in brain regions characterize AD (5). Moreover, intracellular neurofibrillary tangles, neuronal dysfunction, neuroinflammation, and death further characterize AD (6). The actual neurodegenerative process begins 20 to 30 years before first clinical symptoms (7). Amelioration of these pathological alterations before their expansion is crucial for an actual cure. Defining of a marker present in blood will facilitate discovery of a therapeutic procedure at the onset of the neurodegenerative process.
Amyloid beta peptide $(A \beta)$ fragments are produced through amyloid precursor protein (APP), which is a type I transmembrane glycoprotein (8). The proteolysis of the APP by enzymes including the $\beta$ - and $\gamma$-secretase activity is called amyloidogenesis. The beta-site APP-cleaving enzyme 1 (BACE1) has been identified as an important $\beta$-secretase in that process (9). Many studies suggested that BACE1 is essential for the amyloid $\beta$ protein production, causing $A D(10,11)$. BACE1 is also found in several tissues including blood, and for this reason, BACE1 could a good candidate for biomarker analysis $(12,13)$.

Another AD risk gene is clusterin (CLU) known as apolipoprotein $\mathrm{J}(A P O J)(14)$, and it directly binds $A \beta$ and regulates the $A \beta$ pathology (15). It has been shown that CLU also regulates the inflammation and oxidative stress in the brain (16). Therefore, CLU causes neuronal dysfunction via the accumulation of fibrillar amyloid plaque (17). The CLU protein levels were found elevated in the frontal cortex and hippocampus in AD (18). 
These data strongly suggested that BACE1 and CLU may play an important role in the pathogenesis of $A D$ via regulation of the brain amyloid burden. This study was conducted to show the relation between the CLU and BACE1 mRNA levels and AD.

\section{METHODS}

The study protocol was approved by the Ethical Committee of Clinical Research of Istanbul University School of Medicine. Fifty patients with $A D$ were included in the patient group, and 50 healthy volunteers were included in the control group. Written informed consent was obtained from patients who participated in this study.

\section{RNA Isolation and Quantitative Real-Time Polymerase Chain Reaction}

The peripheral blood at the amount of $3 \mathrm{~mL}$ was collected from the patient and control groups and transported in an Ethylenediaminetetraacetic acid (EDTA) anticoagulant solution. The RNA was extracted from blood using the TRIzol reagent (Qiagen Inc., Germany) according to the manufacturer's protocol. The concentration of the RNA solution was tested, with the ratio of OD260/OD280 $>1.80$. The reverse transcriptase reactions were performed with the SensiFAST CDNA Synthesis kit (Bioline USA Inc.). The polymerase chain reactions (PCR) were carried out with a total volume of $20 \mu \mathrm{L}$ containing $2 \mu \mathrm{L}$ of Total RNA, $4 \mu \mathrm{L}$ of $5 x$ TransAmp Buffer, $1 \mu \mathrm{L}$ of reverse transcriptase and $13 \mu \mathrm{L}$ of DNase/RNase free-water. The reactions were subjected to $25^{\circ} \mathrm{C}$ for $10 \mathrm{~min}, 42^{\circ} \mathrm{C}$ for $15 \mathrm{~min}, 85^{\circ} \mathrm{C}$ for $5 \mathrm{~min}$, and $4^{\circ} \mathrm{C}$ hold.

For quantitative real-time PCR (qPCR), the GAPDH gene was used as an endogenous reference gene for the RNA expres- sion detection. The GPCR reactions were performed with the SensiFAST SYBR No-ROX Kit (Bioline USA Inc.). The PCR primers were 5'-AAC CTG CCA AAT ATG ATG AC-3' (forward) and 5'-TTG AAG TCA GAG GAG ACC AC-3' (reverse) for GAPDH, 5'-TGA TCC CAT CAC TGT GAC GG-3' (forward) and 5'-GCT TTT TGC GGT ATT CCT GC-3' (reverse) for the CLU gene, $5^{\prime}$ TGG AGG GCT TCT ACG TTG TC-3' (forward), and 5'-CAG AGT GGC AGC AGC ATG AAG AG-3' (reverse) for the BACE-1 gene. The GPCR reactions were carried out with a total volume of 20 $\mu \mathrm{L}$ containing $10 \mu \mathrm{L}$ of $2 x$ SensiFAST SYBR No-ROX Mix, $1.6 \mu \mathrm{L}$ of $f$ primers, $5 \mu \mathrm{L}$ of template, and $8.4 \mu \mathrm{L}$ of DNase/RNase freewater. The qPCR reactions were subjected to hot start at $95^{\circ} \mathrm{C}$ for $2 \mathrm{~min}$, followed by denaturation at $95^{\circ} \mathrm{C}$ for $5 \mathrm{~s}$, annealing $60^{\circ} \mathrm{C}$ for $10 \mathrm{~s}$, and extension at $52^{\circ} \mathrm{C}$ for $10 \mathrm{~s}$ using the real-time detection system. The expression of genes was quantified by measuring the cycle threshold $(\mathrm{Ct})$ values and normalized using the $2^{-\triangle \Delta C T}$ method relative to the GAPDH RNA.

\section{Statistical Analysis}

Statistical analyses were performed using the Statistical Package for Social Sciences version 22.0 (IBM Corp., Armonk, NY, USA) package program. The Kolmogorov-Smirnov, analysis of variance, and the Mann-Whitney $U$ and Spearman's rho tests were used in the statistical analysis of the data. A $p<0.05$ was considered as statistically significant.

\section{RESULTS}

A total of 100 samples were included in the study: 50 samples in the $A D$ group and 50 samples in the control group. The AD group consisted of 33 males and 17 females, while the control group consisted of 24 males and 26 females. The number of patients with dementia was 42 in the $A D$ group, and the mean

Table 1. Clinical parameters of Alzheimer's disease group

\begin{tabular}{|c|c|c|c|c|c|c|c|}
\hline \multirow[b]{2}{*}{ Parameters } & \multicolumn{3}{|c|}{ Alzheimer's disease group } & \multicolumn{4}{|c|}{ Control group } \\
\hline & Min & Max & Mean \pm SD & Min & Max & Mean \pm SD & $p$ \\
\hline Age (year) & 58 & 102 & $81.64 \pm 8.39$ & 24 & 66 & $37.4 \pm 10.06$ & $<0.001$ \\
\hline Height $(\mathrm{cm})$ & 150 & 187 & $165 \pm 9$ & 150 & 189 & $169 \pm 9.6$ & 0.022 \\
\hline Weight (kg) & 48 & 98 & $70.78 \pm 13.7$ & 50 & 108 & $76.9 \pm 16.05$ & 0.040 \\
\hline Glucose (mg/dL) & 64 & 366 & $124.7 \pm 52.68$ & 74 & 125 & $92.15 \pm 10.5$ & $<0.001$ \\
\hline Total cholesterol (mg/dL) & 92 & 264 & $197.28 \pm 35.89$ & 109 & 311 & $195.1 \pm 42.3$ & 0.28 \\
\hline LDL (mg/dL) & 53 & 176 & $109.94 \pm 21.67$ & 48 & 224 & $114.65 \pm 34.1$ & 0.694 \\
\hline $\mathrm{HDL}(\mathrm{mg} / \mathrm{dL})$ & 21 & 89 & $45 \pm 12.58$ & 30 & 87 & $51 \pm 12.62$ & 0.015 \\
\hline Triglycerides (mg/dL) & 48 & 475 & $209.54 \pm 104.54$ & 45 & 278 & $111.17 \pm 60.1$ & $<0.001$ \\
\hline B12 (pg/mL) & 94 & 580 & $287.5 \pm 80.74$ & & & & \\
\hline Folate $(\mu \mathrm{g} / \mathrm{dL})$ & 1.69 & 60 & $10.03 \pm 9.21$ & & & & \\
\hline TSH (mIU/l) & 0.01 & 8.33 & $2.5 \pm 2.2$ & & & & \\
\hline T3 (ng/dL) & 0.98 & 4.8 & $2.6 \pm 1$ & & & & \\
\hline $\mathrm{T} 4$ ( $\mu \mathrm{g} / \mathrm{dL})$ & 0.47 & 4.11 & $2.03 \pm 0.86$ & & & & \\
\hline
\end{tabular}


Table 2. Correlation analysis of BACE1, CLU, and other parameters

\begin{tabular}{l|c|c|c|c|c|}
\hline $\begin{array}{l}\text { Spearman's rho } \\
\text { correlation }\end{array}$ & $\begin{array}{c}\text { CLU expression } \\
\text { in AD group }\end{array}$ & $\begin{array}{c}\text { BACE1 expression } \\
\text { in AD group }\end{array}$ & $\begin{array}{c}\text { Total } \\
\text { cholesterol }\end{array}$ & HDL & T4 \\
\hline CLU expression in AD group & - & $0.000^{*}$ & 0.46 & 0.14 & 0.46 \\
\hline BACE1 expression in AD group & $0.000^{*}$ & - & 0.9 & 0.17 & 0.94 \\
\hline Total cholesterol & 0.46 & 0.9 & - & $0.000^{*}$ & $0.002^{*}$ \\
\hline HDL & 0.14 & 0.17 & $0.000^{*}$ & - & 0.13 \\
\hline T4 & 0.46 & 0.94 & $0.002^{\star}$ & 0.13 & - \\
\hline $\begin{array}{l}\text { BACE1: beta-site APP-cleaving enzyme 1; CLU: clusterin; AD: Alzheimer's disease; HDL: high-density lipoprotein; T4: tetraiodothyronine } \\
\text { * } 0.002\end{array}$
\end{tabular}

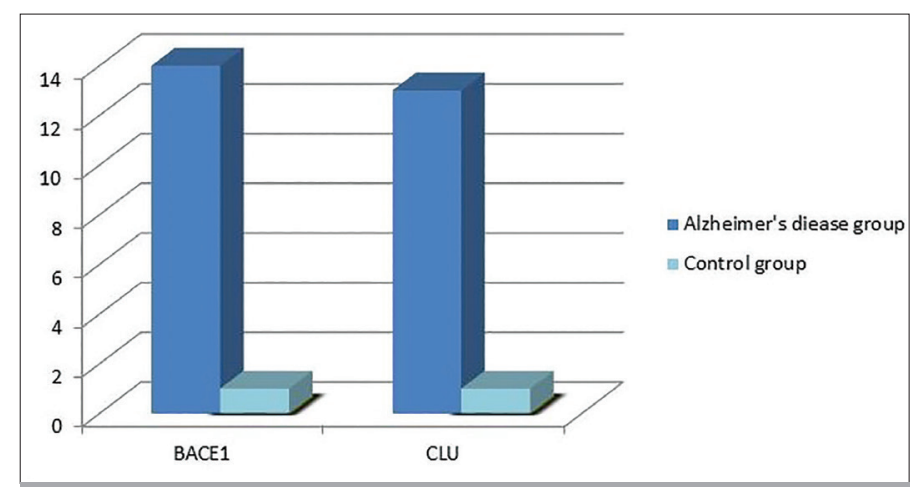

Figure 1. BACE1 and CLU gene expression changes in groups BACE1: $\beta$-site amyloid precursor protein-cleaving enzyme 1; CLU: clusterin

duration of dementia was $5.71 \pm 3.4$ years. The mean age of the $A D$ group was $81.64 \pm 8.39$, and the mean age of the control group was $37.4 \pm 10.06(p<0.001)$. Only 1 patient had EOAD, while others had LOAD. The clinical parameters of the AD group are given in Table 1. Vitamin B12, folate, thyroid-stimulating hormone (TSH), triiodothyronine (T3), and tetraiodothyronine (T4) values were not found in the control group of the clinical parameters given in Table 1. When the parameters in the patient and control groups were compared, they were significantly different between the groups $(p<0.05)$, except for the total cholesterol and low-density lipoprotein (LDL). There was no statistically significant difference in the expression of BACE1 and CLU genes in the patient and control groups $(p=0.64$ and $p=0.53$, respectively). However, BACE1 was 14fold overexpressed in the AD group. Also, CLU was 13-fold overexpressed in the patient group compared to the control group (Figure 1). A positive correlation was found between the BACE1 and CLU gene expressions in the AD group ( $p<0.001)$. Furthermore, total cholesterol was positively correlated with the high-density lipoprotein and T4 levels $(p=0.039)$ in the control group (Table 2).

\section{DISCUSSION}

The BACE1 and CLU genes were found to be overexpressed in the AD group. Although our results were not statistically significant between the groups, we observed the 13- and 14-fold ex- pression changes. Moreover, the expression of BACE1 and CLU was positively correlated in the AD group $(p<0.001)$.

Alzheimer's disease (AD), the most common encountered neurodegenerative disease, is often characterized by progressive dementia affecting the episodic memory (3). A number of novel risk genes were identified for LOAD, the most common type of $A D$, and CLU is one of these genes (19). Normally, CLU released from cells is a stress-activated adenosine triphosphate-independent molecular chaperone, and it plays a role in the inhibition of apoptosis and protein homeostasis/ proteostasis (20). Chen et al. (20) showed that CLU interacted with $\beta$-amyloid peptide (21) and was associated with AD. Furthermore, CLU variants have been shown to increase the $A D$ risk in association with Tau protein (22). Yu et al. (23) reported that elevated CLU expression levels in AD affected brain tissues. Modestly increased CLU expression levels in the frontal and temporal cortex were observed in another study (24). Plasma CLU levels were also found to be positively associated with a rapid clinical progression in AD (25). Thus, researchers suggested that CLU might be evaluated as a potential biomarker in the diagnosis of $\operatorname{AD}(14,23)$. However, some studies did not find a diagnostic value of CLU in $\operatorname{AD}(26,27)$. We found elevated CLU expression levels (13-fold higher) in the peripheral blood of $A D$ patients, but our result was not statistically significant $(p>0.05)$.

One of the early pathogeneses of $A D$ is $A \beta$, and the BACE1 regulates the production of $A \beta$. BACE1 is mostly presented within late endosomes at the presynaptic terminals of patient brains, and it increases synaptic $A \beta$ levels (28). The role in the formation of $A \beta$ peptides has made BACE1 a therapeutic target for $A D$ (29). BACE1 showed an increased activity in the brain tissue and cerebrospinal fluid of subjects with mild cognitive impairment and probable AD (30). Studies showed the upregulation of BACE1 in the brain tissues (29) and plasma of patients with AD (31). High plasma levels of BACE1 were suggested as a possible biomarker for the $A D$ risk (30). When we compared the $A D$ group to the control group, we observed the overexpression of BACE1 (14-fold higher). Moreover, we found positively correlated BACE1 and CLU expression levels in the AD group. This may be derived from the effects each protein has on $A \beta$ peptides. 


\section{CONCLUSION}

Our results show that BACE1 and CLU play a role in the pathology of AD. High expression levels of these genes in plasma could make possible biomarkers for AD. Furthermore, these genes may be evaluated as potential therapeutic targets. More studies are required to elucidate the role of these genes in the mechanism of $A D$ pathology.

Ethics Committee Approval: Ethics committee approval was received for this study from the Ethical Committee of Clinical Research of İstanbul University School of Medicine.

Informed Consent: Written informed consent was obtained from patients who participated in this study.

Peer-review: Externally peer-reviewed.

Author Contributions: Concept - H.A., B.Ç., S.P., S.T., H.H.P.; Design H.A., B.Ç., S.P., S.T., H.H.P.; Supervision - H.A., B.Ç., S.P., S.T., H.H.P.; Resources - H.A., B.Ç., S.P., S.T., H.H.P.; Materials - H.A., S.T.; Data Collection and/or Processing - B.Ç., S.P.; Analysis and/or Interpretation- H.A., B.Ç., S.P., S.T., H.H.P.; Literature Search - H.A., B.Ç., S.P., S.T., H.H.P.; Writing Manuscript - H.A., B.Ç., S.P., S.T., H.H.P.; Critical Review - H.A., B.Ç., S.P., S.T., H.H.P.

Conflict of Interest: The authors have no conflict of interest to declare.

Financial Disclosure: This study was supported by İstanbul University Scientific Research Project Unit (Project No: 29034).

\section{REFERENCES}

1. Chiorcea-Paquim AM, Enache TA, Oliveira-Brett AM. Electrochemistry of Alzheimer disease amyloid beta peptides. Curr Med Chem 2018; 25: 4066-83. [CrossRef]

2. Alzheimer's Association. 2015 Alzheimer's disease facts and figures. Alzheimers Dement 2015; 11: 332-84. [CrossRef]

3. Tellechea P, Pujol N, Esteve-Belloch P, Echeveste B, García-Eulate MR, Arbizu J, et al. Early- and late-onset Alzheimer disease: Are they the same entity? Neurologia 2018; 33: 244-53. [CrossRef]

4. Nural N, Alkan S. Individuals with Alzheimer's in Home Care. Turkiye Klinikleri J Intern Med Nurs-Special Topics 2018; 4: 53-9.

5. Cabrera E, Mathews P, Mezhericher E, Beach TG, Deng J, Neubert TA, et al. A $\beta$ truncated species: Implications for brain clearance mechanisms and amyloid plaque deposition. Biochim Biophys Acta 2018; 1864: 208-25. [CrossRef]

6. Ising C, Heneka MT. Functional and structural damage of neurons by innate immune mechanisms during neurodegeneration. Cell Death Dis 2018; 9: 120. [CrossRef]

7. Holtzman DM, Morris JC, Goate AM. Alzheimer's disease: the challenge of the second century. Sci Transl Med 2011; 3: 77. [CrossRef]

8. Sosa LJ, Cáceres A, Dupraz S, Oksdath M, Quiroga S, Lorenzo A. The physiological role of the amyloid precursor protein as an adhesion molecule in the developing nervous system. J Neurochem 2017; 143: 11-29. [CrossRef]

9. Decourt B, Sabbagh MN. BACE1 as a potential biomarker for Alzheimer's disease. J Alzheimers Dis 2011; 24: 53-9. [CrossRef]

10. Zhang S, Wang Z, Cai F, Zhang M, Wu Y, Zhang J, et al. BACE1 Cleavage Site Selection Critical for Amyloidogenesis and Alzheimer's Pathogenesis. J Neurosci 2017; 37: 6915-25. [CrossRef]
11. Bao J, Qin M, Mahaman YAR, Zhang B, Huang F, Zeng K, et al. BACE1 SUMOylation increases its stability and escalates the protease activity in Alzheimer's disease. Proc Natl Acad Sci USA 2018; 115: 3954-9. [CrossRef]

12. Nafisi-Far N, Ghafouri-Fard S, Panah AST, Sayad A, Taheri M. A gender dimorphism in up-regulation of BACE1 gene expression in schizophrenia. Metab Brain Dis 2018; 33: 933-7. [CrossRef]

13. Andaleon A, Mogil LS, Wheeler HE. Gene-based association study for lipid traits in diverse cohorts implicates BACE1 and SIDT2 regulation in triglyceride levels. PeerJ 2018; 6:e4314. [CrossRef]

14. Tan L, Wang HF, Tan MS, Tan CC, Zhu XC, Miao D, et al. Alzheimer's Disease Neuroimaging Initiative. Effect of CLU genetic variants on cerebrospinal fluid and neuroimaging markers in healthy, mild cognitive impairment and Alzheimer's disease cohorts. Sci Rep 2016; 6: 26027. [CrossRef]

15. Kang SS, Kurti A, Wojtas A, Baker KE, Liu CC, Kanekiyo T, et al. Identification of plexin A4 as a novel clusterin receptor links two Alzheimer's disease risk genes. Hum Mol Genet 2016; 25: 3467-75. [CrossRef]

16. Woody SK, Zhao L. Clusterin (APOJ) in Alzheimer's Disease: An Old Molecule with a New Role. In: Moretti D, editor. Update on Dementia. IntechOpen, 2016; DOI: 10.5772/64233. [CrossRef]

17. Wojtas AM, Kang SS, Olley BM, Gatherer M, Shinohara M, Lozano PA, et al. Loss of clusterin shifts amyloid deposition to the cerebrovasculature via disruption of perivascular drainage pathways. Proc Natl Acad Sci USA 2017; 114: 6962-71. [CrossRef]

18. Lidström AM, Bogdanovic N, Hesse C, Volkman I, Davidsson P, Blennow K. Clusterin (apolipoprotein J) protein levels are increased in hippocampus and in frontal cortex in Alzheimer's disease. Exp Neurol 1998; 154: 511-21. [CrossRef]

19. Karch CM, Jeng AT, Nowotny P, Cady J, Cruchaga C, Goate AM. Expression of novel Alzheimer's disease risk genes in control and Alzheimer's disease brains. PLoS One 2012; 7: e50976. [CrossRef]

20. Wilson MR, Zoubeidi A. Clusterin as a therapeutic target. Expert Opin Ther Targets 2017; 21: 201-13. [CrossRef]

21. Chen P, Wang C, Ma X, Zhang Y, Liu Q, Qiu S, et al. Direct Interaction of Selenoprotein R with Clusterin and Its Possible Role in Alzheimer's Disease. PLoS One 2013; 8: e66384. [CrossRef]

22. Zhou Y, Hayashi I, Wong J, Tugusheva K, Renger JJ, Zerbinatti C. Intracellular clusterin interacts with brain isoforms of the bridging integrator 1 and with the microtubule-associated protein Tau in Alzheimer's disease. PLoS One 2014; 9: e103187. [CrossRef]

23. Yu JT, Tan L. The role of clusterin in Alzheimer's disease: pathways, pathogenesis, and therapy. Mol Neurobiol 2012; 45: 314-26. [CrossRef]

24. Baig S, Palmer LE, Owen MJ, Williams J, Kehoe PG, Love S. Clusterin mRNA and protein in Alzheimer's disease. J Alzheimers Dis 2012; 28 337-44. [CrossRef]

25. Thambisetty M, Simmons A, Velayudhan L, Hye A, Campbell J, Zhang $Y$, et al. Association of plasma clusterin concentration with severity, pathology, and progression in Alzheimer disease. Arch Gen Psychiatry 2010; 67: 739-48. [CrossRef]

26. Silajdžić E, Minthon L, Björkqvist M, Hansson O. No diagnostic value of plasma clusterin in Alzheimer's disease. PLoS One 2012; 7: e50237. [CrossRef]

27. IJsselstijn L, Dekker LJ, Koudstaal PJ, Hofman A, Sillevis Smitt PA, Breteler MM, et al. Serum clusterin levels are not increased in presymptomatic Alzheimer's disease. J Proteome Res 2011; 10: 2006-10. [CrossRef]

28. Ye X, Feng T, Tammineni P, Chang $Q$, Jeong YY, Margolis DJ, et al. Regulation of Synaptic Amyloid- $\beta$ Generation through BACE1 Retrograde Transport in a Mouse Model of Alzheimer's Disease. J Neurosci 2017; 37: 2639-55. [CrossRef] 
29. Gong G, An F, Wang Y, Bian M, Yu LJ, Wei C. miR-15b represses BACE1 expression in sporadic Alzheimer's disease. Oncotarget 2017; 8: 91551-7. [CrossRef]

30. Shen Y, Wang H, Sun $Q$, Yao H, Keegan AP, Mullan M, et al. Increased Plasma Beta-Secretase 1 May Predict Conversion to Alzheimer's Dis- ease Dementia in Individuals With Mild Cognitive Impairment. Biol Psychiatry 2018; 83: 447-55. [CrossRef]

31. Feng L, Liao YT, He JC, Xie CL, Chen SY, Fan HH, et al. Plasma long non-coding RNA BACE1 as a novel biomarker for diagnosis of Alzheimer disease. BMC Neurol 2018; 18: 4. [CrossRef] 